\title{
Olhares de crianças a relevar a polifonia da cidade
}

\author{
Gisele Schwede - Associação Catarinense de Ensino, Joinville/SC, Brasil \\ Andrea Vieira Zanella - Universidade Federal de Santa Catarina, Florianópolis/SC, Brasil
}

\begin{abstract}
Resumo
Este artigo apresenta resultados de uma pesquisa que teve por objetivo compreender os sentidos atribuídos por crianças às relações que estabelecem com a cidade. Os recursos metodológicos para coleta de informações consistiram na realização de uma Oficina de Fotografia seguida de entrevistas para leitura das imagens produzidas. Discute-se aqui reflexões sobre o que apresentam os discursos e imagens fotográficas produzidos pelas crianças, analisados à luz do enfoque histórico-cultural em Psicologia e das contribuições de autores do Círculo de Bakhtin. Os resultados indicam que as crianças reconhecem haver circunstâncias em que ocupam uma situação de exclusão social, pois criticam tais circunstâncias e seus efeitos. Todavia, entendem que o bairro em que residem oferece benefícios para seus moradores. Conclui-se que a cidade em que se deu a pesquisa permite o agenciamento de múltiplas possibilidades, pois com fronteiras e sentidos intercambiantes, caracteriza-se por sua condição polifônica que propicia diversidades de experiências.

Palavras-chave: Cidade; Fotografia; Polifonia; Criança; Sentidos.
\end{abstract}

Children's eyes revealing the polyphony of the city

\begin{abstract}
This article presents the results of a research that aimed at understanding the meanings imputed by children to the relationships they establish with the city. The methodological resources used to collect information consisted of a Workshop of Pictures followed by interviews for the reading of the images produced. Here, reflections are made about what is presented in the speeches and photographic images produced by the children, analyzed in the light of the historycultural focus on Psychology and of the contributions of authors of Bakhtin's circle. The results indicate that the children recognize that there are circumstances in which they are in a situation of social exclusion, since they criticize such circumstances and their effects. However, they understand that the suburb where they live offer benefits to its residents. The conclusion is that the city where the research took place provides multiple possibilities because, with interchangeable borders and meanings, it is characterized by its polyphonous condition, which propitiates different experiences.

Keywords: City; Picture; Polyphony; Child; Meanings.
\end{abstract}

Vislumbres de los niños revelando la polifonía de la ciudad

\begin{abstract}
Resumen
Este artículo presenta los resultados de una investigación cuyo objetivo fue comprender los sentidos que los niños atribuyen a las relaciones que establecen con la ciudad. Los recursos metodológicos para obtener la información consistieron en la realización de un Taller de Fotografía seguido de entrevistas para percibir la lectura de las imágenes producidas. Aquí se discuten las reflexiones sobre lo que se presenta en los discursos e imágenes fotográficas producidas por los niños, analizadas bajo la luz del enfoque histórico-cultural de la Psicología y de las contribuciones de los autores del Círculo de Bakhtin. Los resultados indican que los niños reconocen que existen circunstancias en las que ocupan una situación de exclusión social, ya que critican tales circunstancias y sus efectos. Además, entienden que el barrio en el que viven ofrece beneficios a sus habitantes. Se concluye que la ciudad en la que se realizó la investigación permite el agenciamiento de múltiples posibilidades, ya que, al tener fronteras y sentidos intercambiables, se caracteriza por su condición polifónica que propicia una gran variedad de experiencias.

Palabras clave: Ciudad; Fotografía; Polifonía; Niños; Sentidos.
\end{abstract}

Neste artigo são apresentados os resultados de uma investigação cujo propósito foi o de compreender os sentidos que crianças atribuem às relações que estabelecem com os espaços urbanos. As crianças participantes foram convidadas a produzir imagens fotográficas daquilo que lhes fosse significativo da/na cidade. As relações com a cidade, por conseguinte, consistiram no foco das reflexões das pesquisadoras e dos participantes da pesquisa, entretecidas com as contribuições de autores que foram eleitos para compor o diálogo. Buscou-se, com a investigação, promover o encontro entre essas vozes, tornando-as audíveis no coro que configura novos matizes ao conhecimento sobre as crianças contemporâneas e suas

Disponivel em wnw.scielo.br relações com a cidade, espaço polifônico constituído por e constitutivo dos sujeitos que o habitam.

As discussões fundamentaram-se nos aportes teóricos de Vigotski e Bakhtin, entendendo que as contribuições desses autores são importantes guias para a leitura dos discursos e imagens produzidas pelos sujeitos convidados a participar da pesquisa, isto é, uma leitura de sujeitos que são parte e ativamente participam de determinada condição social e tempo histórico.

Atentar para a complexidade das relações sociais que acontecem na cidade enseja em se lançar um olhar para pessoas que a habitam e nesta pesquisa, um olhar para as crianças. Para isso, é necessário compreender a 
infância considerando as peculiaridades que caracterizam as crianças de grupos variados e de contextos diversos, bem como os diferentes usos que fazem dos espaços e condições da cidade, a partir do entendimento da infância não como uma fase da vida natural a todos, com características universais que acobertam suas ações. A criança, moradora e transeunte da urbe, apropria-se dos sentidos deste outro que é a cidade contemporânea para continuamente produzir-se como sujeito, marcado pelas condições de possibilidades que ali se apresentam.

A análise da relação da infância com a rua pode ser conhecida, dentre outros autores, por meio da discussão feita por Matias e Francischini (2007). Para eles: "A rua, que antes acolhia as crianças e outros grupos de pessoas, sustentando e favorecendo formas muito próprias de convivialidade, foi tornada espaço público e palco do surgimento de uma nova ordem social, de uma urbanidade diversa e tensa" (p. 1). Ou seja, acompanhar o percurso histórico da relação da infância com a cidade permite saber que concomitantemente ao desenvolvimento de novos modos de relação com a infância na Modernidade, também foi se dando a cisão entre a infância e a rua, já que a infância, que antes possuía a rua enquanto espaço de sociabilidade, passou a ser tutelada por médicos, juristas, pedagogos e psicólogos, ficando a partir de então circunscrita aos espaços domésticos.

Se atualmente há, por um lado, restrições legais quanto ao uso e ocupação dos espaços da cidade visando à garantia da integridade física e psicológica das crianças (Lei n. 8069, de 13 de julho de 1990), por outro, estas aparecem como figurantes da trama que compõe a complexidade da cidade e impõem sua presença: as crianças são usuárias do transporte público, divertem-se nos shopping centers, circulam via deslocamentos de sua residência à escola e a outros espaços sociais em trajetos marcados pela densidade de experiências que lhes são oportunizadas. As crianças ocupam, portanto, os espaços da cidade, suas ruas, travessas, cruzamentos, e ali se apropriam dos variados movimentos, das ambiguidades e desigualdades que a conotam. Se circulam, podem, com seus deslocamentos perceber as contradições da sociedade da qual participam e a qual (re)produzem, e esses olhares, uma vez tensionados, constituem-se como condição para a leitura das desiguais possibilidades e dos diferentes lugares sociais que conotam as relações na e com a cidade.

\section{As crianças e a cidade: olhares em foco}

Ao escolher pesquisar as relações das crianças com a cidade, optou-se concomitantemente por pesquisar a linguagem fotográfica, entendendo-se o ato de fotografar como uma prática social prenhe de sentidos, polissêmica e polifônica. Vive-se contemporaneamente em uma realidade que se apresenta atravessada por uma profusão de imagens, apresentadas nos outdoors, televisão, internet, redes sociais, enfim, nas tecnologias da informação e comunicação onipresentes nos tempos atuais. A imagem de tal modo se generalizou que é a forma por excelência de se comunicar as informações de um mundo em constante movimento e transformação.

Considerando esse cenário e buscando contribuir com as pesquisas que vêm sendo desenvolvidas no encontro da psicologia com a fotografia ${ }^{2}$, buscou-se com a pesquisa realizada prestar atenção às imagens, atentando para os contextos onde se inscrevem e visando aguçar o olhar para os signos que a habitam. O foco do trabalho consistiu em ampliar a compreensão dos enunciados objetivados nas fotografias, permitindo, desse modo que a imagem fotográfica se imiscuísse nessa produção de conhecimento, potencializando a compreensão dos modos de produção da subjetividade contemporânea.

É importante ressaltar, tal como postula Rouillé (2009), que há no Ocidente uma longa tradição de se considerarem os aspectos documentais da imagem fotográfica, fazendo com que a compreensão da fotografia como enunciado seja objeto de querela entre os estudiosos da questão. Porém, é necessário pontuar que a compreensão da imagem fotográfica como discurso não exclui dela sua possibilidade documental. O convite, ao contrário, é o de entender a fotografia não apenas como uma representação do real: pode ser documento, sem dúvida, mas também discurso que traz no seu bojo o enunciado de um sujeito que tem no objeto fotografado a possibilidade de um encontro com um outro que toma parte do acontecimento fotografar. Conforme Rouillé (2009), fotografar não seria mais apenas

representar, registrar, captar aparências, mas exprimir situações humanas que ultrapassem amplamente a ordem do visivel. A imagem não é mais o produto de um ato pontual, mas resultado de um trabalho que ultrapassa, $e$ muito, o curto momento da filmagem". (p. 183-184)

Nesse sentido, não se compreende a fotografia como um dispositivo auxiliar para dizer o mesmo de outro modo. Ao contrário, compreende-se a fotografia como dispositivo subjetivador, que tem a potência de mudar o modo como se olha o mundo: o olhar é outro a partir da leitura das imagens. A fotografia, portanto, é uma produção cultural e, como tal, provoca efeitos de subjetivação agenciados pelos signos nela veiculados, que modificam o modo de ver o mundo e o modo de ser no mundo. 
Afirma-se, então, que toda fotografia veicula discursos de sujeitos situados historicamente. Sendo discursos, seus significados podem ser lidos, apropriados e ressignificados pelo contemplador da imagem, seja este seu próprio autor (então já também contemplador), sejam outras pessoas capazes de estabelecer com essa obra novas relações de sentido. Explica Bakhtin (2003), ao dizer que o processo de compreensão de um discurso é marcado pela responsividade sígnica, que o signo produzido está respondendo a outro signo em um encadeamento infindável e dinâmico. Assim sendo, na contemplação de uma fotografia pode se dar o encontro de consciências mediadas pelo signo, uma consciência compreendendo outra, e esta, produzindo novos sentidos a essa compreensão primeira.

O olhar que contempla a realidade e dela retira os ingredientes para a produção fotográfica, para modificar com essa produção a realidade primeira, é resultado de uma construção histórica. Olhar mediado semioticamente, construído na história das relações, olhar que concebe outros olhares, que forja redes urdidas na história dos sujeitos que se cruzam, que cruzam olhares e palavras, olhar possível de ser esteticamente educado.

Pensar nesta educação estética do olhar que uma pesquisa-intervenção tem a potência de provocar exige certa reflexão, pois a leitura das imagens é um exercício de compromisso com a experiência racional e sensível de tomada de consciência (Jobim e Souza \& Lopes, 2002). Antes, cabe elucidar a compreensão de estética aqui adotada. Afirma Zanella (2006) que é estética a "dimensão sensível, enquanto modo específico de relação com a realidade, pautado por uma sensibilidade que permita reconhecer a polissemia da vida e transcender o caráter prático utilitário da cultura capitalística" (p. 36).

Partindo dessa concepção, pode-se afirmar que o objeto das relações estéticas está justamente na relação estabelecida entre o sujeito e esse objeto, marcada pela história e contexto social desse sujeito contemplador, bem como, pela história desse objeto dentro desse contexto social. Para se pensar a dimensão estética da imagem fotográfica, há que se buscar aprender a olhar o mundo indo aos detalhes, decompondo mosaicos, como diz Jobim e Souza (2002), para então melhor enxergar a figura que reina majestosa no todo de uma revelação figurativa. Para que isso seja possível, não se pode separar a imagem da palavra, pois é por esta última que a imagem enriquece e ganha contornos. Decompõem-se as imagens em palavras para então poder devolver ao outro as possíveis interpretações daquilo que é visto. As imagens podem, assim, se tornar mediadoras de um diálogo entre pessoas que buscam outros modos de narrar sua experiência no discurso (Jobim e Souza, 2002).

$\mathrm{Na}$ pesquisa ora apresentada, teve-se então o propósito de que as imagens da cidade produzidas pelas crianças provocassem nelas, quando da contemplação de sua produção, além da memória do próprio ato fotográfico, também os sentidos das relações estabelecidas com a cidade, a fim de agenciar a produção de outros sentidos. Recursos de visibilidade, as imagens produzidas puderam, então, propiciar a construção de outros sentidos para a cidade, em um processo dialógico que aproxima os múltiplos valores, visões de mundo e entoações que a sociedade da qual são parte produz acerca da cidade e que permite às crianças também tomar parte neste processo mais amplo de (re)construção incessante da cultura..

\section{Método}

Participaram da pesquisa vinte crianças residentes na periferia da cidade de Joinville, em Santa Catarina, estudantes do $5^{\circ}$ ano de uma escola pública municipal, todas com idades entre dez e doze anos. A aproximação dessas crianças se deu a partir da escola, pois é esta a instituição que, por obrigatoriedade legal no Brasil, congrega as crianças. Porém, apenas os primeiros encontros foram realizados nesse espaço, pois esta pesquisa não tinha por objetivo discutir as relações engendradas nos contextos de escolarização formal. Assim, elegeu-se como local para os encontros com as crianças uma sala de reuniões de uma igreja localizada próxima da escola em que estudavam. O local é costumeiramente disponibilizado para atividades da escola e de outras instituições do bairro, logo, as crianças tinham familiaridade com o lugar.

Com exceção de poucas crianças participantes da pesquisa, todas são filhas de famílias migrantes, que vieram para Joinville de outras regiões do Brasil almejando melhores condições de vida, buscando acesso a trabalho, educação e saúde. Em sua maioria são famílias com baixa renda e que trabalham muitas horas por dia, em ocupações informais ou em trabalho autônomo. Em virtude disso, as crianças precisam ficar sob seus próprios cuidados, sozinhas em casa ou cuidando dos irmãos mais novos, ou ainda em centros de educação infantil ou na escola.

Todas as crianças moram em um bairro em que há considerável número de habitações em terrenos localizados em áreas de ocupação irregular, isto é, locais em que as pessoas têm posse dos terrenos por estarem vivendo há anos neles, porém não possuem a propriedade regularizada da área. Trata-se de um bairro distante do centro e, em virtude disso, as crianças possuem pouco acesso a equipamentos urbanos, 
disponíveis apenas em regiões centrais. $\mathrm{Na}$ ocasião da realização da pesquisa, as crianças ou os pais mencionaram que há poucos locais para lazer; que o saneamento básico ainda não atende a todos e que as pessoas lá residentes precisam se locomover para outros bairros a fins de realizar atividades como a utilização de serviços bancários.

Durante a investigação, quatro foram os meios para a coleta de informações: 1) observações; 2) o desenvolvimento da oficina de fotografia; 3) a realização de entrevistas; 4) as fotografias produzidas pelas crianças. Concomitante às observações, desenvolveram-se os procedimentos necessários para atender às determinações legais dispostas na Resolução 196/1996, do Conselho Nacional de Saúde, o que ensejou a realização de encontros com os pais para a obtenção de seu consentimento para a participação das crianças na pesquisa ${ }^{3}$.

Inicialmente esteve-se presente na sala de aula das crianças que seriam convidadas a participar da pesquisa, observando o desenrolar da aula e conversando com elas. Posteriormente às observações, desenvolveu-se, ao longo de cinco encontros, uma oficina de fotografia voltada à construção de vínculos, apresentação de alguns conceitos básicos sobre fotografia e, principalmente, discussões sobre aspectos da cidade. Em um dos encontros foi disponibilizada para cada um dos participantes da pesquisa uma câmera fotográfica descartável de 27 poses para que pudessem criar, ao longo de uma semana, imagens fotográficas do que lhes fosse significativo na/da cidade, isto é, do que lhes chamasse a atenção, sejam lugares, pessoas, construções, paisagens. A última etapa, da coleta de informações, consistiu na realização de entrevistas individuais com as crianças para a leitura das imagens por elas produzidas.

Ao todo foram realizadas treze entrevistas, com duração aproximada de 40 minutos cada, gravadas em equipamentos de áudio e posteriormente transcritas. Todas aconteceram no mesmo espaço em que foi realizada a Oficina.

A análise dos discursos produzidos nos encontros com as crianças pesquisadas orientou-se pelas discussões sobre o processo de produção de conhecimentos e as questões do discurso segundo a perspectiva bakhtiniana. Para Bakhtin (2003), a produção de conhecimentos sempre ensejará um encontro entre consciências diferentes que gerará um diálogo produzido entre ambas. Diz este autor que:

Qualquer objeto do saber (incluindo o homem) pode ser percebido e conbecido como coisa. Mas o sujeito como tal não pode ser percebido e estudado como coisa porque, como sujeito e permanecendo sujeito, não pode tornar-se mudo; consequentemente, o conbecimento que se tem dele só pode ser dialógico. (p. 400, grifo no original)

Sendo dialógico, o caráter dos discursos construídos necessariamente será determinado pela relação destes com outros discursos, com ditos e não ditos, presentes e ausentes. Plurais, portanto. Isso significa dizer que nem o texto das pesquisadoras (a vOz das pesquisadoras), nem o texto dos sujeitos pesquisados poderia submergir um ao outro, pois essa coexistência é que pode justamente revelar os pontos de tensão entre eles e também entre várias outras vozes sociais que se apresentam no discurso. Só assim podese revelar este campo de embate que há no encontro de diferentes discursos, condição de possibilidade que se presentifica à medida que não se comete o erro de compreender dialogismo como a relação direta com outro, pois esta é apenas a face mais externa da dialogia: necessário se faz prestar atenção ao encontro polifônico das múltiplas vozes que podem ser ouvidas em um único texto ou nas relações com um interlocutor ausente.

Em uma pesquisa que pressupõe tal concepção de sujeito (e de linguagem), é necessário conceber o conhecimento a ser produzido levando em consideração o contexto do qual faz parte e ativamente participa e a história que o atravessa. O mesmo vale para o pesquisador em ciências humanas, também atravessado por particularidades discursivas que implicam determinada ética. Nessa perspectiva, há que se analisare os discursos, buscar esclarecer seus presumidos, seu auditório. É preciso perscrutar as vozes sociais que ali interagem e compõem uma complexa e tensa sinfonia.

\section{Resultados e Discussão}

Construída em terras que fizeram parte do dote de Francisca Carolina, irmã do Imperador Dom Pedro II, Joinville foi colonizada por imigrantes europeus vindos para o Brasil na segunda metade do século XIX. Para Silva (2004), na historiografia oficial da cidade há uma espécie de mito fundador ${ }^{4}$, frequentemente reiterado, que busca valorizar os primeiros acontecimentos da fundação da cidade. Além disso, desde suas primeiras décadas a cidade foi marcada pelo desenvolvimento industrial, sendo, portanto, também marcada pelo ethos do trabalho e pelo mito do empreendedorismo, que seria próprio do imigrante europeu. Tal desenvolvimento levou a cidade a receber o título de Manchester Catarinense, em alusão à industrializada cidade inglesa de mesmo nome. É também conhecida como Cidade da Dança, por sediar o maior festival de danças do mundo. Por fim, vale lembrar que é chamada de Cidade das Flores, título que 
teve origem em 1906, quando Afonso Pena, visitou Joinville e se encantou com seus jardins (Schwede, 2010).

Atualmente, a exemplo de outras cidades brasileiras de mesmo porte, Joinville possui substancial parcela de sua população constituída por migrantes, de etnias diversas. O fluxo migratório vindo de diversas regiões do país passou a se dar principalmente a partir da década de 1970, sendo em sua maioria constituído de agricultores expulsos da área rural pela modernização do campo e motivados pela atração que a cidade exercia em termos de oportunidades de emprego e consequente acesso a bens de consumo, melhor conforto, dentre outras condições de vida. Além disso, a crescente urbanização, acelerada com a instalação de indústrias metalúrgicas, ensejava a contratação de mão de obra em significativos números e que não estava disponível na cidade.

Consequência de tal quadro foi que quantidade significativa desses migrantes, deparando-se com condições adversas de moradia e sem disponibilidade financeira para instalar-se em locais adequados, começou a adquirir terrenos em situação irregular. Muitas regiões em que estão localizados esses terrenos, adquiridos de especuladores imobiliários, são áreas de manguezais que deveriam estar sob proteção permanente, já que se trata de um ecossistema costeiro de transição entre o ambiente terrestre e o marinho.

Essas questões estão presentes nas falas e imagens de várias crianças que participaram da pesquisa. Descendentes destes migrantes (ou elas mesmas nascidas em outros lugares e trazidas para Joinville pelos pais), as crianças revelam a saudade que ficou do lugar que deixaram para trás, mas principalmente, dos familiares, que raramente têm a oportunidade de visitar. Thais ${ }^{5}$, de onze anos, revela como foi o processo da mudança do Nordeste do Brasil para Joinville:

É uma coisa que me lembra da minha vó e do meu vô, que eles moram em Pernambuco, onde que a gente morava.... Chorei bastante quando a minha vó, quando a gente veio embora... Daí a gente veio embora para cá. Meu pai começou a construir, com o meu tio, a minha casa, dai a gente veio embora para cá.

Como tantos migrantes, a família de Thais possuía parentes morando em Joinville, o que facilitou o processo de reconstrução de referências de pertencimento a algum grupo social, posto que o familiar ou o amigo que já está na cidade e recebe o migrante faz a mediação dos recém-chegados às especificidades do lugar. Mas essa mediação é insuficiente no sentido de amenizar o sofrimento dessas pessoas, conforme é discutido por Niehues (2000):
O desaparecimento do antigo modo de vida causa muito sofrimento ao migrante. [...] A solidão, o medo de andar nas ruas, de perder-se, de ser enganado, de ser roubado o acompanha; uma angústia permanente para quem não estava acostumado com um ambiente de movimentação constante. (p. 174)

A forma de ocupação dos espaços da cidade, presente na produção imagética e na fala de algumas crianças, revela as desigualdades presentes no desenvolvimento das cidades e, mais do que isso, propicia às crianças uma determinada aprendizagem da cidade e das práticas sociais comuns na sociedade contemporânea. Embora a mobilidade urbana delas seja limitada por não estarem autorizadas a transitar por todos os espaços da cidade, ou em virtude do impraticável custo do transporte urbano, elas têm oportunidades de aprender e interpretar o modo como a cidade se organiza. E o fato de terem que habitar em moradias precárias, em regiões também precárias, não lhes passa despercebido. Bad Boy, nove anos, explica como é para ele e outras crianças habitar estas regiões:

Eu quis mostrar [indicando a imagem da figura 1$]$ que quando chove, lá na minha casa, que dai fica muita lama, daí não dá de passar. Porque quando a gente quer fazer pedido ${ }^{6}$, quando não tem alguma coisa, ou quando a gente quer ir para a escola, e dai vai para sair e dai se suja tudo. Nesta foto dá de ver que lá, que quando chove enche, vai água demais em tudo, em todos os lugares, todas as casas.... Eu quis mostrar a minha rua, como que é. Ela é ruim, porque quando chove, dai a gente vai para ir brincar com amigos e a lama começa a respingar na roupa..

Bad Boy não fotografa sua casa a partir da rua, mas fotografa a rua a partir da porta de sua casa: vê a rua de saibro, com água empoçada da chuva. O garoto mostra ao leitor de sua imagem a experiência que precisa continuamente vivenciar para alcançar o outro (a escola, os amigos). Pode-se refletir com Castro (2004) acerca dessa necessidade de adentrar e ultrapassar a rua para a aprendizagem da cidade e das relações sociais: "Atravessamos os umbrais de casa para ganhar o mundo e a cidade. A rua é o meio. Através da rua entra-se em contato com o que é desconhecido e não-familiar. A rua começa logo ali... na porta da casa" (p. 40). Para Bad Boy, encontrar os outros significa já chegar com as roupas respingadas de lama. A exclusão verifica-se assim na organização do espaço da cidade, que implica as roupas respingadas desse menino, pois é fácil constatar que a imagem produzida por Bad Boy revela segregação e afastamento que o impedem de ter acesso a certos bens e recursos. Prestando atenção ao que está presumido no enunciado de Bad Boy e que não foi explicitado em sua fala, pode-se conhecer o lugar social desvalorizado que é acessível aos 
moradores das áreas de ocupação irregular, submetidos à situação de sofrimento psicossocial constante ${ }^{7}$.

Porém, a família de Bad Boy resiste e criativamente adapta o que era um salão de festas para fazer desse lugar uma casa, a morada da família: Porque aqui nesta casa, aqui na verdade é um salão de festa, dai aqui nestes lugares aqui, nós toquemo de dividi... Porque as casas são importantes, porque sem as casas nós não... nós morava na rua ${ }^{8}$.

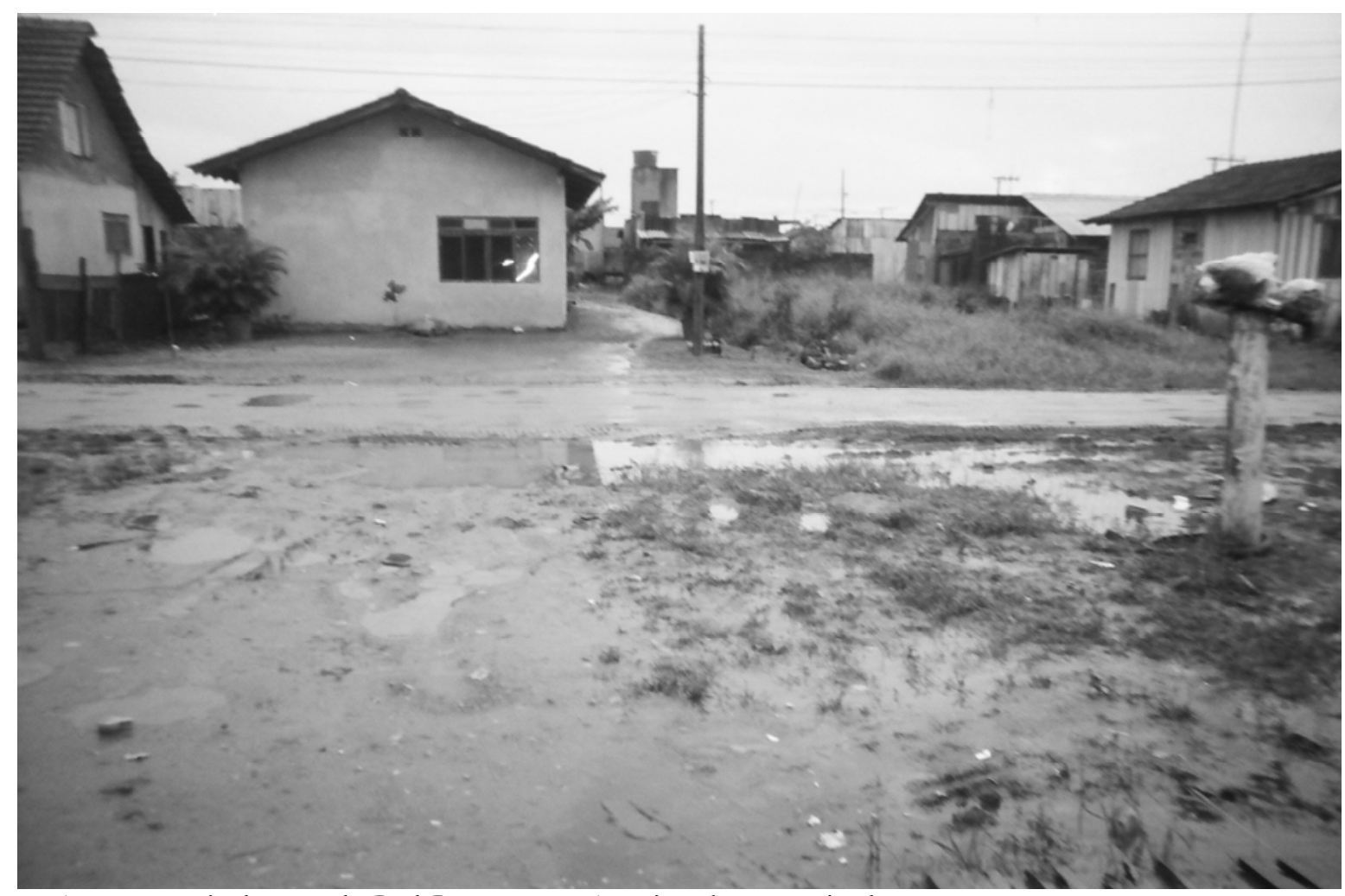

Figura 1. A rua a partir da casa de Bad Boy. Fonte: Arquivo das pesquisadoras.

Pode-se afirmar que resolver criativamente as situações que o processo desigual de produção e distribuição do espaço da cidade impõe às famílias cotidianamente possibilita a ocorrência de transformações subjetivas que fazem frente aos modos padronizados de se lidar com as dificuldades.

$\mathrm{Na}$ imagem fotográfica da Figura 1, apesar da precariedade da rua e das residências indicada por Bad Boy, também se pode verificar a existência de rede de energia elétrica e um ponto de recolhimento de lixo. Ou seja, alguns serviços públicos chegam até as regiões de ocupação irregular, pois no Brasil as empresas concessionárias desses serviços, como o de fornecimento de energia elétrica, preferem oficializar o fornecimento ao invés de combater ligações clandestinas que acabam sendo estabelecidos. Isso ocorre porque todo novo assentamento urbano necessariamente vai buscar energia elétrica e água. Se o fornecimento regular do serviço não existe, os moradores costumam perfurar novos poços para obter água e realizar ligações clandestinas à rede de energia. Essas opções ocasionam uma série de riscos: o perfuramento de poços na área urbana pode promover a contaminação das águas subterrâneas. As ligações clandestinas, além de onerar o custo da energia elétrica para todos os usuários regulares, já que as concessionárias distribuem o prejuízo ao aumentar a tarifa, podem causar uma série de acidentes graves. Assim, para minimizar esses riscos, as empresas optam por fornecer de modo regularizado esses serviços à população, independente das condições e da localização de suas residências (Pinto, 2006).

As consequências dessas práticas, além de definitivamente consolidar o assentamento irregular, também são apresentadas por Hadassa, dez anos, em suas imagens e enunciados:

Hadassa: A prefeitura tá ficando relaxada de deixar esgoto a céu aberto deste jeito. [Hadassa indica a imagem da figura 2]. É muito ruim, falta de saneamento... Já pensou? Vai que cai uma criança aí dentro? Sei que não vai dar muito dano, mas deve ser horrivel, né? Ou acontece um acidente, se cai um caminhão ou um carro? 


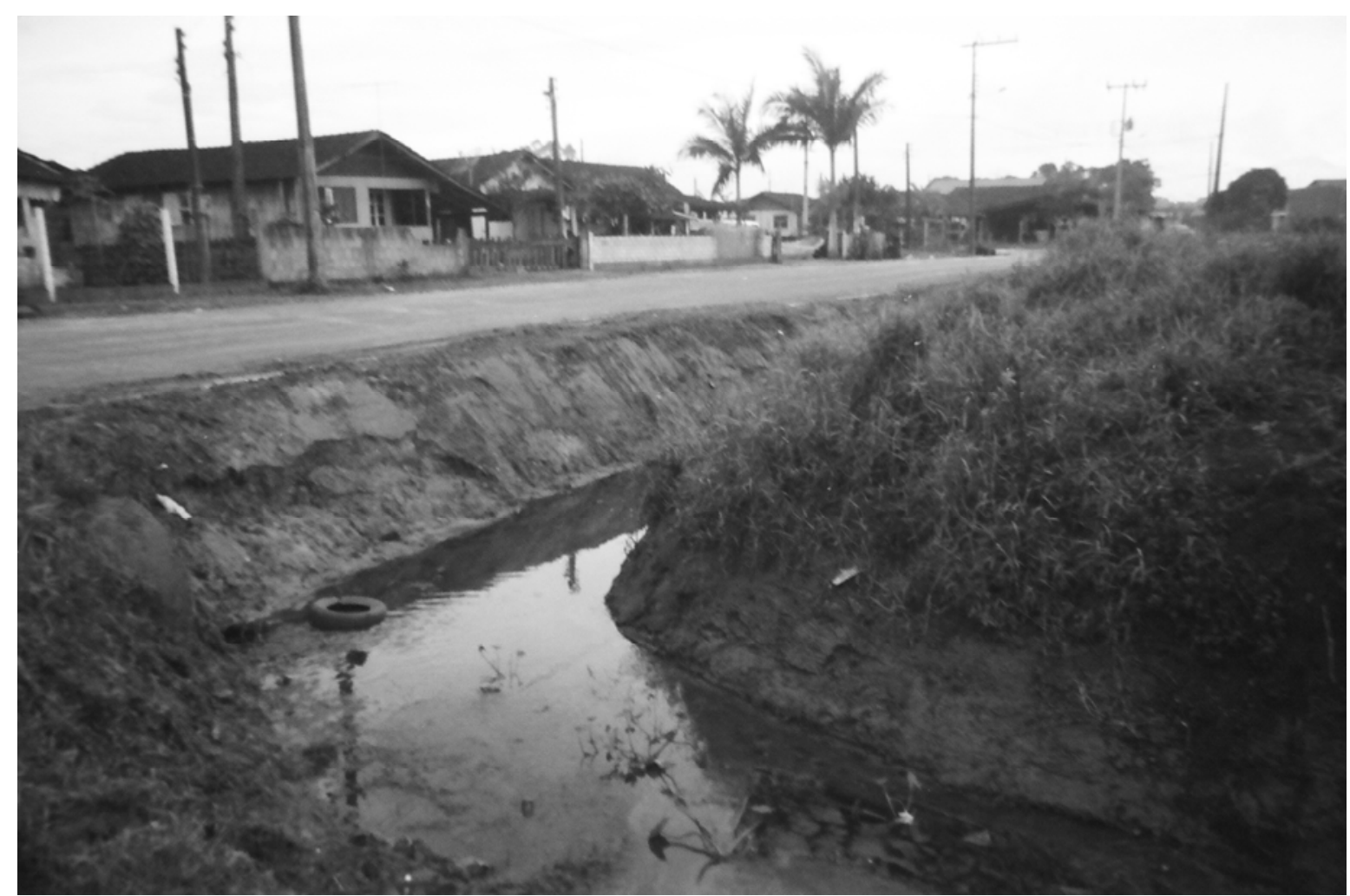

Figura 2. A valeta que, segundo Hadassa, oferece riscos à população. Fonte: Arquivo das pesquisadoras.

A imagem fotográfica permite ver uma valeta, que para Hadassa é resultante da falta de cuidado da prefeitura. Segundo Pinto (2006), de fato é comum no Brasil, no que se refere ao saneamento, que se faça a ligação de água. Já em relação ao esgoto isso não acontece, criando o esgoto a cén aberto como se vê na figura 2, foco de transmissão de doenças.

Logo, são garantidos alguns direitos aos moradores dessas áreas, tais como o fornecimento de água, luz e o recolhimento de lixo, mas que podem ser compreendidos como paliativos: afinal, mascaram uma série de problemas sociais decorrentes da perversidade de um sistema econômico que ocasiona mádistribuição de renda e que, consequentemente, leva essas famílias a buscar escapar do ônus de pesados custos de imóveis localizados em regiões regulares e providas de todos os serviços básicos.

Porém, se as crianças percebem e apontam as deficiências de seu bairro e da cidade no oferecimento de infraestrutura e padrões mínimos da habitação que garantam saúde e qualidade de vida, elas também entendem que o bairro oferece uma série de benefícios para seus moradores e valorizam esses benefícios, tais como o posto de saúde e centros de educação infantil localizados no bairro, serviços disponibilizados pelo estado. Além disso, também consideram como benefícios a existência de farmácia, mercado e transporte público, conforme enuncia Carol, dez anos, ao olhar as imagens por ela produzidas:

A farmácia! [indicando a imagem da figura 3]. Quando a gente precisa de alguma coisa, remédio, estas coisas, tem na farmácia. E os ônibus. Porque quando a gente precisa ir alguma emergência, a gente tem o ônibus para ir.

O que é compreendido por Carol como benefício no bairro onde reside e enunciado em seu discurso imagético e verbal é o acesso a alguns equipamentos, como a farmácia por ela fotografada (Figura 3) ou o transporte público. O enunciado de Carol revela valores compartilhados por ela com uma comunidade maior. Vejamos: cerca de metade da população que hoje mora em Joinville é constituída por migrantes oriundos de áreas rurais e seus descendentes, vindos para essa cidade a partir da década de 1970. Essas pessoas, atendendo às campanhas publicitárias das empresas locais e desesperançosas do campo em virtude da tecnologização do trabalho rural, vieram para a cidade em busca de melhores condições de sobrevivência, melhoria da qualidade de vida, acesso a bens e recursos, acesso à saúde e, principalmente, à educação para os filhos. 


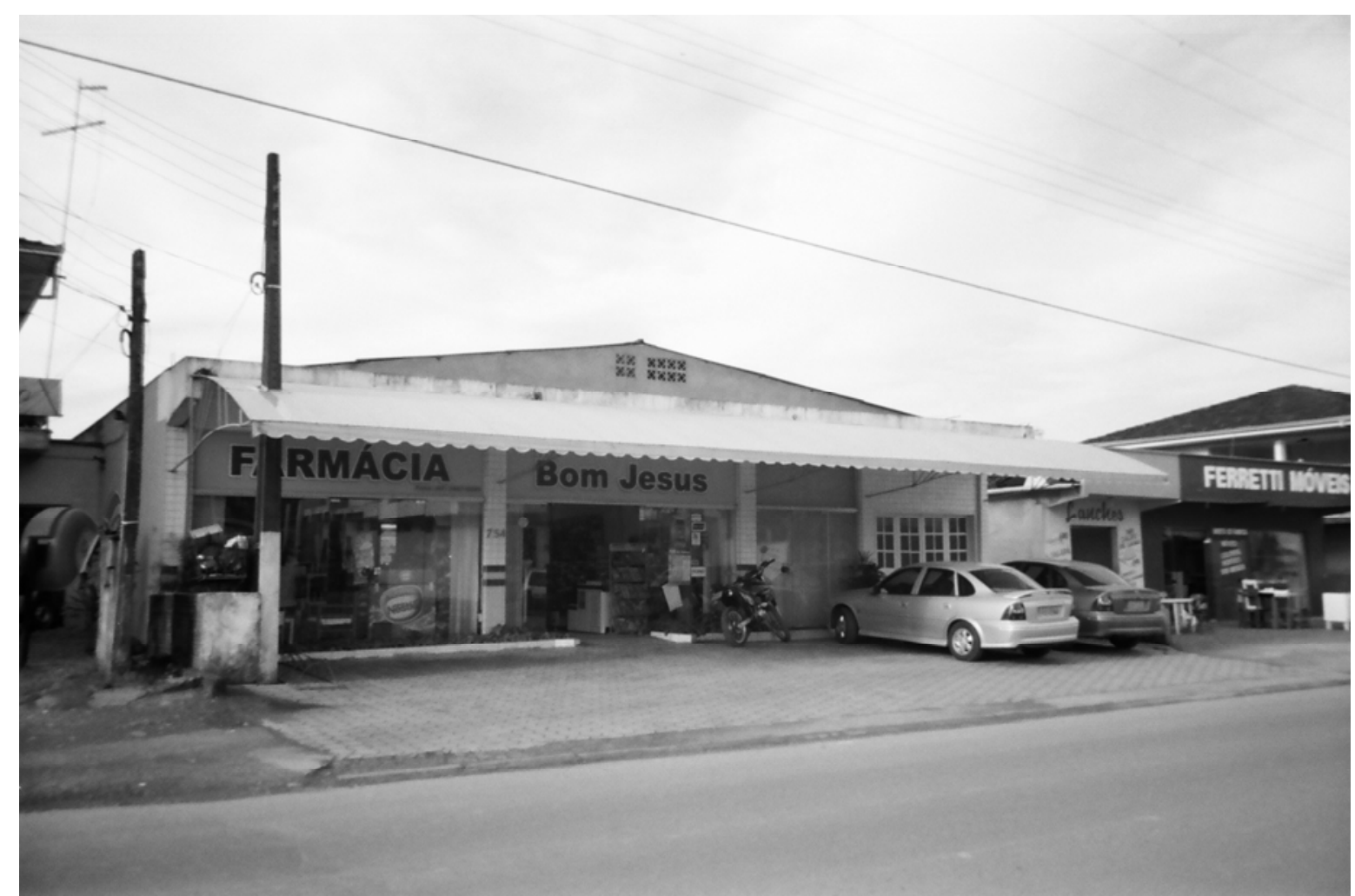

Figura 3. A farmácia, indicada por Carol como um dos benefícios do bairro. Fonte: Arquivo das pesquisadoras

Na cidade, a escola, o posto de saúde, a farmácia, o hospital, dentre outros equipamentos que podem tornar a vida mais amena, estão próximos se comparados com as grandes distâncias que os separam de tais recursos em seus locais de origem. Assim, percebe-se que Carol apropriou-se de um sentido dado por esta população migrante (de que ela também é parte) acerca da vida na cidade, atribuindo seus próprios sentidos à utilização dos equipamentos urbanos.

Desse modo, se por um lado as crianças indicam as deficiências da cidade que dificultam seu cotidiano e acesso a alguns direitos básicos, mostrando isso ao fotografarem o que é significativo na cidade, por outro lado não deixam de indicar o que gostam e valorizam em seu bairro, evidenciando com as imagens produzidas aquilo a que têm acesso e reconhecem como um benefício. Os sentidos agenciados pela cidade, conforme as crianças pesquisadas foram apontando, relevam relações ambíguas, já que a cidade faz emergir sentimentos como satisfação pelo que disponibiliza aos moradores e medo e insatisfação com algumas condições encontradas.

Decorrente da passagem da casa para a rua, a conquista do espaço público enseja para a criança a aprendizagem de novos modos de se relacionar com aqueles que são e muitas vezes continuarão sendo estranhos. Trata-se de uma transformação pela qual passa a criança ao precisar se desgarrar de casa, da proteção e da segurança do que é conhecido que, segundo Castro (2004), mobiliza sentimentos de medo, angústia e insegurança.

Circulando pela cidade, novas experiências ficam disponíveis a elas, de modo a também experienciarem novos sentimentos daí decorrentes. Isso é revelado especialmente por algumas meninas entrevistadas, como Nycole, dez anos, que verbalizou o desejo de crescer logo, pois sendo menina teme ser estuprada e não ter como se defender. Sendo criança, reconhece que fica em uma posição vulnerável em relação aos adultos, pois não tem tanta força física. Lari, onze anos, também diz que estar em certos lugares públicos enseja em estar vulnerável a ser caçoada pelos meninos:

"Eles não respeitam, sabe, eles ficam falando nome e a minha mãe não gosta que eu fique com os piá9. Se a gente dá confiança, os piá ficam me xingando, ficam falando besteira, né? Daí a minha mãe não gosta".

Lari evidencia, em seu discurso, que há riscos no processo de ocupar e conquistar os espaços da cidade em que mora, pois para ocupá-los precisa aprender e se apropriar dos diferentes signos, que revelam ao mesmo tempo o socialmente permitido e o vetado. Transitar no espaço público da cidade impõe, desse modo, a construção de formas de se manejar a impessoalidade própria do encontro com desconhecidos. Às vezes essas possibilidades de se acessar a diversidade da cidade são impedidas pelos pais, no sentido de proteção da criança no espaço da casa. Assim,

Psico-USF, Bragança Paulista, v. 18, n. 3, p. 395-406, set/dez 2013 
circunscritas aos locais em que a elas é autorizado circular, no processo dessa aprendizagem dos signos que compõem a comunicação urbana, as crianças precisam construir quem são na rua.

Considerando então que o espaço autorizado para a criança é limitado aos lugares entendidos pelos pais como sendo seguros para sua permanência e circulação, mas que cada vez mais as crianças inserem-se no processo de ocupar a cidade, fazendo parte $\mathrm{e}$ participando das relações sociais que se desenrolam nesse contexto, entende-se que as crianças participam da trama da construção dessas relações, desde que se apropriam, fazem análises e reflexões acerca da organização e chegam a conclusões sobre a cidade.

Mas e o que as crianças não fotografaram e não verbalizaram durante a pesquisa?

Escolher produzir um conjunto de enunciados imagéticos que tem um limite, já que o equipamento disponibilizado a elas durante a realização da Oficina permite a produção de vinte e sete imagens, enseja deixar de produzir outros discursos. Nesse sentido, chama a atenção no conjunto das fotografias produzidas pelas crianças a predominância de imagens realizadas no próprio bairro em que residem.

Vários são os motivos para isso, conforme elas mesmas comentam, assim como também revelam que gostariam de ter fotografado outros lugares e falam que lugares são estes, a exemplo de Indi, dez anos:

"Ah, en queria ter fotografado a entrada de Joinville, que

lá, eu nunca fui lá e queria também ter fotografado também outras coisas assim que... estas coisas assim que fica muito longe e não deu para mim ir..."

$\mathrm{O}$ enunciado de Indi faz aqui emergir a discussão sobre as (im)possibilidades de uso e de circulação nos espaços da cidade e as experiências daí decorrentes, que fomentam a produção da subjetividade. Conforme destacado por Cassab (2001), "mais do que o lócus onde essa subjetividade se produz, a cidade se 'personifica' e impõe a esses jovens determinadas restrições e/ou possibilidades na configuração dessas subjetividades" (p. 209). Enquanto algumas crianças sequer cogitam a saída do bairro para fotografar outros lugares que a cidade propicia, algumas não o fazem por faltar o dinheiro para o pagamento do transporte, conforme explica Bad Boy:

Lá no centro, queria ir... Mas não tinha dinheiro, que meu tio não quis pagar meu padrasto e dai lá no... um monte de lugar que eu não posso ir, que eu não pude ir. Só que dai a gente não tinba dinbeiro, né? Só tinha dinheiro para comprar comida. Eu gostaria de ter fotografado a Vigorelli, lugares bonitos.

Nas fotografias de Bad Boy, o menino expressa as condições inadequadas de seu bairro, conforme discussões anteriores. Ele fala que gostaria de ter fotografado lugares bonitos, dentre os quais a Vigorelli, vila de pescadores localizada no município. Se gostaria de fotografar lugares bonitos, seu bairro parece ficar excluído dessa categoria. Por outro lado, é por falta de dinheiro que não fotografou tais lugares, pois são estes os que eu não posso ir.

Bad Boy possui um saber acerca dos lugares que pode e que não pode frequentar, em virtude das possibilidades concretas que se apresentam. Essa leitura que faz sobre o acesso à cidade é resultado não apenas de suas próprias conclusões a partir do cotidiano vivenciado, mas é fundamentalmente resultado da organização coletiva que preceitua como se dá a disposição do trabalho, da circulação, das trocas e das oportunidades no cenário da cidade.

Por outro lado, ainda que se possa aderir à ideia da existência de uma espécie de fronteira que separa as regiões acessíveis às pessoas que ocupam a cidade, há que se atentar para o fato de que a exclusão social possível de ser percebida no enunciado de Bad Boy, que afirma que há lugares que não pode ir, é fenômeno não exclusivo da impossibilidade do trânsito pela cidade. Além das determinações da lógica capitalista que propicia a valorização de certos espaços urbanos e a precarização de outras, são construídos e difundidos sentidos que definem o status dos diferentes lugares da cidade e seus respectivos habitantes.

Esses sentidos, apropriados desde cedo por esses citadinos, são levados em consideração quando decidem os locais que irão ocupar e por onde transitar. Decorre disso que as pessoas constroem uma espécie de mapa, nele inscrevendo os sentidos atribuídos às múltiplas vivências de cidade e que servirão de referência para suas futuras experiências no espaço urbano. Esses sentidos, coletivamente produzidos e particularmente apropriados, constituem as condições de possibilidades dos mapas que cada pessoa constrói da cidade a partir de suas experiências, mapa este constantemente posto em xeque. A ocupação de lugares diferentes pode muitas vezes oferecer desafios para aqueles que se dispõe a se apropriar da cidade. Ter acesso a outros lugares, cruzar fronteiras visíveis e invisíveis, pode então significar ter que enfrentar a lama e os buracos da estrada, as distâncias e o gasto com o transporte. Mas pode ensejar em se apropriar de lugares diferentes do cotidiano, conforme Maicon, dez anos, apresenta na imagem da Figura 4 e em sua fala:

Maicon: Aqui eu quis mostrar muita... [indicando a figura 4] Bastante coisa boa... O pôr do sol, né? Que é bem bonito. É bem legal. É uma tranquilidade também, que é ali. Amor, paz... Tem garça. Assim... Bastante coisa. A senhora já foi para o Recanto das Garças?... É bem legal, passa um monte de balsa, tem bancos de areia assim... É bem bonito! 


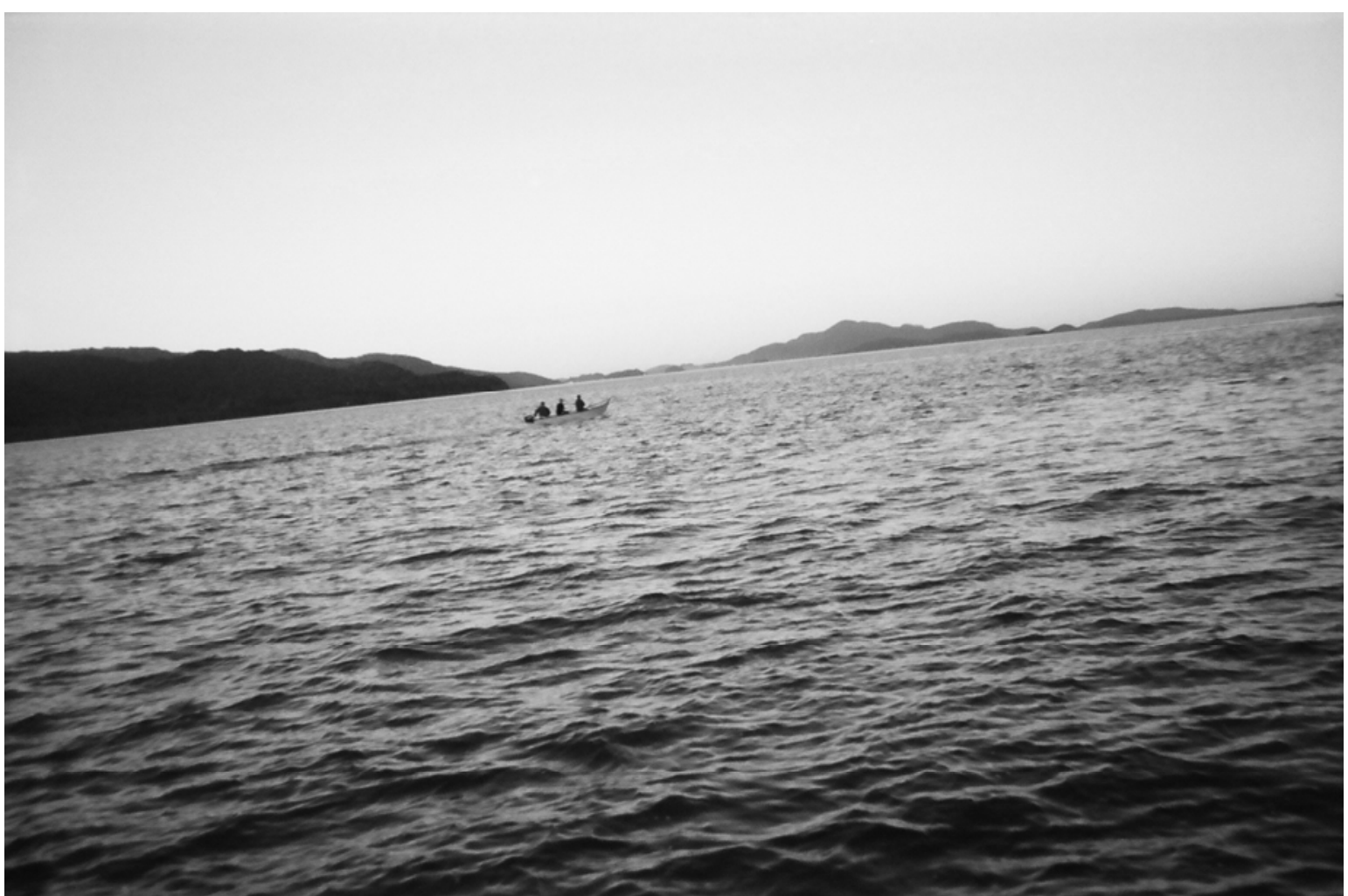

Figura 4. A baía da Babitonga, fotografada por Maicon. Fonte: Arquivo das pesquisadoras.

O discurso provocado pela contemplação de sua produção faz Maicon agenciar, além da memória do passeio recente realizado com a família para um lugar tradicionalmente reconhecido como belo, a lembrança de outros passeios realizados por lugares diferentes. A imagem fotográfica propicia a Maicon revelar outras experiências de aprendizagem da cidade. $\mathrm{O}$ menino revela, em sua imagem fotográfica uma relação afetiva estabelecida com determinado espaço da cidade que orna a memória que tem do lugar.

As fotografias produzidas convidam a pensar sobre os jogos de visibilidade e invisibilidade e sobre o que está de fato disponível para o exercício de olhar das crianças que ocupam determinados espaços da cidade. A escolha de se produzirem certos discursos imagéticos e verbais e de se silenciar em relação a outros possíveis permite afirmar que, paradoxalmente, no mesmo espaço territorial, há a produção de várias cidades: produz-se a cidade que traz em sua tônica a dança, as flores, a nobreza, o trabalho e o desenvolvimento, isto é, uma cidade idealizada, prenhe dos sentidos produzidos a partir de alguns signos visíveis e que sob alguns aspectos estão disponíveis apenas para o olhar de alguns. Mas, juntamente com essa cidade, produz-se também cidades outras, algumas vezes distantes, algumas bonitas, outras tantas precárias, que podem às vezes parecer subsumidas à cidade idealizada.

\section{Considerações finais}

As fotografias produzidas pelas crianças possibilitaram conhecer os modos como se relacionam com as condições que a vida na cidade lhes apresenta. Para elas, a relação com a cidade é marcada pela necessidade de se apropriar de seus signos. Essa apropriação pode emergir de novas experiências vivenciadas por elas, como, por exemplo, a própria atividade de leitura das fotografias produzidas. Essas experiências podem vir a suscitar novos afetos e sentidos a serem atribuídos ao espaço urbano, e neste processo contínuo de ressignificação das relações com a cidade, criam-se possibilidades de produção de subjetividades outras.

A leitura das fotografias, por sua vez, fomentou a reflexão sobre a cidade e possibilitou compreender sua condição polifônica. A cidade pesquisada, além dos sentidos que aqui se buscou apresentar, enseja outros múltiplos sentidos que contêm e ao mesmo tempo extrapolam aqueles da cidade idealizada. Com fronteiras e sentidos intercambiantes, a mesma Joinville carrega muitas Joinvilles que propiciam uma pluralidade de experiências, às vezes incentivadas, às vezes cerceadas pelo jogo das relações sociais que se estabelecem entre aqueles que a constituem.

Psico-USF, Bragança Paulista, v. 18, n. 3, p. 395-406, set/dez.2013 
Mas a leitura das imagens fotográficas não modifica somente seus artífices: por meio da compreensão de narrativas imagéticas produzidas por crianças é possível compreender os olhares das crianças que habitam as cidades contemporâneas sobre o local e as condições em que vivem. Com essa compreensão podemos, ao fim e ao cabo, talvez ressignificar o próprio papel profissional de intervenção junto a essa população, deslocando a centralidade do saber sobre a infância para as crianças, ou ao menos provocar a tensão entre diferentes saberes, de modo que novos possíveis possam ser enunciados e reconhecidos.

\section{Referências}

Bakhtin, M. M. (2003). Estética da criação verbal. (4a ed.). São Paulo: Martins Fontes.

Cassab, M. A. T. (2001). Jovens pobres e a cidade: a construção da subjetividade na desigualdade. Niterói: Intertexto.

Castro, L. R. (2004). A aventura urbana: crianças e jovens no Rio de Janeiro. Rio de Janeiro: 7 Letras; Faperj.

Ceccim, R. B. \& Palombini, A. L. (2009) Imagens da infância, devir-criança e uma formulação à educação do cuidado. Psicologia e Sociedade, 21(3), 301-312.

Jobim e Souza, S. (2002). O olho e a câmara: desafios para a educação na época da interatividade virtual. Revista Advir, 15(15), 75-81.

Jobim e Souza, S. (2003). O olho e a câmara. Em S. Jobim e Souza (Org.).Educação@pós-modernidade: fiçcoes científicas e crônicas do cotidiano (pp. 69-74). Rio de Janeiro: 7 Letras.

Jobim e Souza, S. (2008). Imagem técnica e estética: sobre os modos de produção da cultura e da subjetividade no mundo contemporâneo. Em A. P. Gouvêa (Org.). Cine Imaginarium: da arte de fazer psicologia, comunicação e cinema (pp. 265-282). Rio de Janeiro: Companhia de Freud \& PUC-Rio.

Jobim e Souza, S. \& Lopes, A. E. (2002). Fotografar e narrar: a produção do conhecimento no contexto da escola. Cadernos de Pesquisa, 116, 61-80.

Jobim e Souza, S. \& Salgado, R. G. (2008). Mikhail Bakhtin e a ética das imagens nos estudos da infância: uma proposta de pesquisa-intervenção. Em J. Correa, L. R. Castro \& V. Besset (Org.). Pesquisa-intervenção na infância e juventude (pp 490513). Rio de Janeiro: NAU.
Lei n. 8069, de 13 de julho de 1990. (1990, 13 de julho). Dispóe sobre o Estatuto da Criança e do Adolescente e dá outras providências. Recuperado em 6 de novembro de 2008, de http://www.planalto.gov.br/ccivil_03/Leis/L8069 .htm.

Matias, H. J. D. \& Francischini, R. (2007). A infância e a rua: imagens cruzadas no Brasil do século XX. XIV Encontro Nacional da ABRAPSO - Diálogos em Psicologia Social: Epistemológicos, Éticos, Políticos, Estéticos e politicas públicas. Anais do XIV Congresso Nacional da Abrapso - Trabalhos Completos.

Niehues, V. D. (2000). De agricultor a operário: lembrancas de migrantes. Dissertação de Mestrado em História, Universidade Federal de Santa Catarina.

Pinto, V. C. (2006, agosto). Ocupaşão irregular do solo urbano: o papel da legislação federal (2006, agosto). Jus Navigandi, 10 (1149).

Rouillé, A. (2009). A fotografia: entre documento e arte contemporânea. São Paulo: Senac.

Sawaia, B. (1995). Psicologia social: aspectos epistemológicos e éticos. Em B. Sawaia \& S. T. M. Lane. Novas veredas da psicologia social. São Paulo: Brasiliense.

Schwede, G. (2010). O paraíso das crianças na Cidade dos Principes: a polifonia urbana revelada em imagens fotográficas. Dissertação de Mestrado em Psicologia, Universidade Federal de Santa Catarina.

Silva, J. G. (2004). Tensões, trabalhos e sociabilidades: bistórias de mulheres em Joinville no século XIX. Joinville: Univille.

Tittoni, J. (Org.). (2009). Psicologia e fotografia: experiências em intervenções fotográficas. Porto Alegre: Dom Quixote.

Zanella, A. V. (2006). "Pode até ser flor se flor parece a quem diga": reflexões sobre educação estética e o processo de constituição do sujeito. Em S. Z. Da Ros, K. Maheirie, \& A. V. Zanella. Relacões estéticas, atividade criadora e imaginação: sujeitos e (em) experiência (pp. 33-47). Florianópolis: NUP/CED/UFSC, 2006.

Recebido em 15/07/2011

Primeira Reformulação em 17/04/2012 Segunda Reformulação em 07/03/2013

Aprovado em 14/05/2013 
Sobre as autoras:

Gisele Schwede é psicóloga, mestre em Psicologia pela Universidade Federal.

Andrea Vieira Zanella é professora associada da Universidade Federal de Santa Catarina e bolsista em produtividade do CNPq. Possui graduação em Psicologia pela Universidade Federal do Paraná (1986), mestrado (1992) e doutorado (1997) em Psicologia da Educação pela Pontifícia Universidade Católica de São Paulo. Realizou estudos pós-doutorais na Università Degli Studi di Roma La Sapienza, em 2009.

Contato com as autoras:

Travessa São José, 490, Centro - CEP 89202-010/ Joinville/SC.

E-mail: gisele.schwede@gmail.com carol.cassiano@gmail.com

\section{Notas:}

1 Este artigo foi elaborado a partir de um recorte da pesquisa de mestrado da primeira autora, orientada pela segunda.

${ }^{2}$ Vale ressaltar que o estudo da fotografia na área da Psicologia tem recebido considerável incremento nos últimos anos no Brasil. Destacam-se, nesse sentido, as pesquisas que vêm sendo realizadas com a coordenação da professora Jaqueline Tittoni (2009), e as investigações que integram o projeto de pesquisa Subjetividade em Imagens: dialogismo e alteridade na produção do conhecimento contemporâneo, coordenado pela professora Solange Jobim e Souza (2002, 2003, 2008 e Jobim e Souza \& Salgado, 2008).

${ }^{3}$ O projeto foi submetido ao Comitê de Ética na Pesquisa com Seres Humanos da UFSC e devidamente aprovado.

${ }^{4}$ Conceito proposto pela filósofa Marilena Chauí, que afirma que "Um mito fundador é aquele que não cessa de encontrar novos meios para exprimir-se, novas linguagens, novos valores e ideias, de tal modo que, quanto mais parece ser outra coisa, tanto mais é a repetição de si mesmo." (Chauí, 2000, p. 5, grifos no original).

5 Para garantir a privacidade das crianças participantes da pesquisa, foram omitidos seus nomes verdadeiros. Os nomes aqui apresentados foram escolhidos por elas próprias.

${ }^{6}$ Fazer pedido é uma expressão local que significa fazer as compras básicas do mês, no mercado.

${ }^{7}$ Segundo Sawaia, este conceito refere-se a: “a fixação do modo rígido de estado físico e mental que diminui a potência de agir em prol do bem comum, mesmo que motivado por necessidades do eu, gerando, por efeito perverso, ações contra as necessidades coletivas e, consequentemente individuais" (Sawaia, 1995, p. 50)

${ }^{8} \mathrm{Na}$ imagem é possível identificar os pais de Bad Boy. A fim de garantir sua privacidade esta imagem não é apresentada.

${ }^{9}$ Piá é uma gíria utilizada na região Sul do Brasil que significa menino. 